\title{
Peran Orang Tua terhadap Hasil Belajar Matematika Materi Aljabar di Masa Pandemi COVID-19
}

\author{
Setya Selaksa Mentari ${ }^{1 *}$, Yatha Yuni ${ }^{2}$, Niken Vioreza ${ }^{3}$ \\ ${ }^{1}$ Spring Garden School, Cikarang-Bekasi, Indonesia \\ ${ }^{2}$ Pendidikan Matematika, STKIP Kusuma Negara, Indonesia \\ ${ }^{3}$ Pendidikan Guru Sekolah Dasar, STKIP Kusuma Negara, Indonesia \\ *setyaselaksa@gmail.com
}

\begin{tabular}{|c|c|}
\hline Article Info & Abstract \\
\hline $\begin{array}{l}\text { Received } \\
19 \text { September } 2021\end{array}$ & $\begin{array}{l}\text { The role of parents is needed in the education of children. The role of } \\
\text { parents in education makes the quality of children's education better. } \\
\text { The purpose of the study was to determine the relationship between } \\
\text { the role of parents and the mathematics learning outcomes of Algebra }\end{array}$ \\
\hline $\begin{array}{l}\text { Revised } \\
02 \text { October } 2021\end{array}$ & $\begin{array}{l}\text { during the Corona Virus Disease } 2019 \text { (COVID-19) Pandemic. The } \\
\text { research sample was } 72 \text { junior high school students in class VII. This }\end{array}$ \\
\hline $\begin{array}{l}\text { Accepted } \\
25 \text { October } 2021\end{array}$ & $\begin{array}{l}\text { study uses quantitative methods with survey techniques. The } \\
\text { instrument is a questionnaire and an objective test. The prerequisite } \\
\text { test used the Liliefors test, and the data were normally distributed. An } \\
\text { analysis of the regression equation shows there is a positive }\end{array}$ \\
\hline Keywords & $\begin{array}{l}\text { relationship between the two variables. Hypothesis testing using the } \\
\text { product-moment correlation test is obtained } r_{\text {count }} \text { more than } r_{\text {table }} \text { at a } \\
\text { significant level of } 5 \% \text {. Because } r_{\text {count }} \text { more than } r_{\text {table, it can be }}\end{array}$ \\
\hline Algebra & concluded that there is a strong relationship between the role of \\
\hline COVID-19 Pandemic & parents and learning outcomes in mathematics. Based on the \\
\hline Learning Outcome & correlation $t$-test, obtained $t_{\text {count }}>t_{\text {table }}$ with $d b=70$. The conclusion is \\
\hline Role of Parents & $\begin{array}{l}\text { that there is a significant positive relationship between the role of } \\
\text { parents and the mathematics learning outcomes of junior high school } \\
\text { students. Parents' attention contributes } 57.15 \% \text { to mathematics } \\
\text { learning outcomes. }\end{array}$ \\
\hline
\end{tabular}

How to Cite:

Mentari, S. S., Yuni, Y., \& Vioreza, N. (2021). Peran Orang Tua terhadap Hasil Belajar Matematika Materi Aljabar di Masa Pandemi COVID-19. Journal of Instructional Mathematics, 2(2), 55-63.

\section{PENDAHULUAN}

Pendidikan merupakan hal yang sangat penting, sebab tanpa pendidikan manusia akan sulit berkembang dan sulit maju. Bahkan tanpa pendidikan, manusia akan terbelakang seperti masyarakat yang tinggal dipedalaman jauh dari pendidikan. Sekalipun mereka hidup berdasarkan pendidikan yang diterima secara turun temurun dari keluarga atau leluhur.

Pendidikan sejak usia dini tak lain merupakan pendidikan yang mencakup beberapa aspek termasuk di dalamnya aspek sosial dan emosional. Aspek sosioemosional berkaitan dengan keterampilan sosial, yakni kemampuan individu dalam bersosialisasi dengan lingkungan sekitarnya (Indrawati dkk., 2020). Perkembangan kemampuan anak bersosialisasi dimulai dari keluarga. Oleh sebab itu keluarga mempunyai peran penting dalam pendidikan anak. Anak mendapatkan pendidikan awal dari keluarga sebelum waktunya bersekolah terutama dari orang tua. Pendidikan dalam keluarga sangat penting dan merupakan pilar pokok 
pembangunan karakter seorang anak (Yoga dkk, 2015; Novrinda dkk., 2017). Pendidikan hendaknya dilakukan secara komprehensif, meliputi seluruh aspek pendidikan, mulai dari persiapan anak sejak lahir sampai kepada upaya memperkuat kemampuan jasmani dan rohani anak, disampaikan dengan nasihat, dengan contoh yang baik serta dengan proses pembiasaan terhadap hal-hal yang baik sehingga berimplikasi pada kepribadian anak di masa dewasa (Anisah, 2017; Martsiswati dkk., 2014).

Dunia saat ini disibukkan dengan mewabahnya COVID-19. Berbagai upaya dilakukan pemerintah untuk memutus rantai penyebaran virus ini, di antaranya dengan mengeluarkan PP Nomor 21 tahun 2020 tentang Pembatasan Sosial Berskala Besar dalam rangka percepatan penanganan pandemi COVID-19 (Kurniati dkk., 2020). Peraturan ini berdampak pada semua aspek kehidupan manusia di belahan bumi manapun, termasuk pendidikan di Indonesia. Pemerintah membatasi berbagai aktivitas termasukan aktivitas kegiatan belajar mengajar di sekolah. Kebijakan ini tidak membuat belajar dihentikan, sehingga memaksa pengelola pendidikan, guru, dan peserta didik untuk tetap mengajar dan belajar dari rumah mulai dari jenjang PAUD sampai Perguruan Tinggi (Kemdikbud, 2020). Kegiatan belajar anak yang dilaksanakan dari rumah, suka atau tidak suka menjadi tanggungjawab orang tua. Belajar dari rumah (BDR) dapat dilihat dari kesiapan orang tua dalam membimbing anak selama BDR. Tidak semua orang tua siap menjadi guru pengganti selama BDR (Yulianingsih dkk., 2020).

Berdasarkan hasil observasi di Sekolah Spring Garden School melalui wawancara dengan guru matematika dan beberapa orang tua di masa pandemi, banyak siswa yang kesulitan memahami materi yang diberikan oleh guru. Kesulitan memahami pelajaran matematika dikarenakan ketidaksiapan siswa dan orang tua menghadapi proses belajar secara daring (Juliya \& Herlambang, 2021). Untuk siswa kelas VII yang masih masa peralihan dari SD ke SMP belajar mandiri sepenuhnya tentu terasa berat, apalagi kurang perhatian dan bimbingan dari orang tua. Berdampak hasil ulangan matematika hampir $80 \%$ dibawah ketuntasan minimal (KKM), keluhan guru matematika di Sekolah Spring Garden School.

Belajar secara daring dari rumah tentunya sangat memerlukan pendampingan dari orang tua atau anggota keluarga lainnya, agar anak ada yang membimbing saat bingung, dan ada dukungan saat mereka bosan (Syahrina, 2021). Peran orang tua adalah keikutsertaan orang tua dalam perkembangan pendidikan anaknya (Lilawati, 2020). Ada lima peran orang tua yaitu: (1) orang tua sebagai fasilitator, (2) orang tua sebagai motivator, (3) peran orang tua sebagai pembimbing, (4) orang tua sebagai pendidik, dan (5) orang tua sebagai pelindung anaknya dari pergaulan yang kurang baik (Fitroturrohmah dkk., 2019). Peran orang tua dapat menentukan keberhasilan pendidikan anaknya, untuk itu penting bagi orang tua menyediakan waktu membimbing serta menemani anak dalam belajar. Hal tersebut dapat menumbuhkan minat dan motivasi anak dalam belajar (Ningsih dkk., 2016) pengetahuan dari orang tua tentang pentingnya perhatian terhadap anaknya akan menentukan keberhasilan prestasi sang anak. Menurut Wulandari dkk. (2017), perhatian dan bimbingan yang dapat dilakukan oleh orang tua pada anak adalah sebagai berikut: (1) Menyediakan fasilitas belajar; (2) Mengawasi kegiatan belajar di rumah; (3) Mengawasi penggunaan waktu belajar anak di rumah; (4) Mengetahui kesulitan anak dalam belajar. Apabila ke-empat peran ini dilakukan orang tua, maka anak tidak mengalami kesulitan dalam belajar daring. Materi matematika yang 
disampaikan guru dalam waktu singkat dan sulit tetap tidak menghambat anak memahami pelajaran matematika. Waktu belajar bersama orang tua jauh lebih banyak dibandingkan bersama guru.

Hasil belajar peserta didik pada hakikatnya merupakan kemampuankemampuan yang dimiliki oleh siswa setelah ia menerima pengalaman belajar (Sudjana, 2009). Hasil belajar adalah perubahan perilaku secara keseluruhan bukan hanya salah satu aspek potensi kemanusiaan saja (Suprijono, 2009). Berdasarkan kedua pendapat ahli tersebut, hasil belajar adalah perubahan sikap atau cara berpikir seseorang setelah mengalami pengalaman dalam proses belajar. Setelah mendapatkan pengalaman maka siswa akan mengetahui hasil belajar yang sudah dilakukan. Berdasarkan Taksonomi Bloom yang diteliti Amelia dkk.,(2016) memperoleh temuan tingkat kognitif siswa kelas VII masih pada ranah $\mathrm{C} 1, \mathrm{C} 2$, dan C3. Pengetahuan (C1) sebesar 92,5\%; tingkat kognitif pemahaman (C2) sebesar $61 \%$; dan tingkat kognitif aplikasi (C3) sebesar 71,2\%. Pada ranah $\mathrm{C} 1$ orang tua tidak mengalami kesulitan membimbing anaknya. Namun pada ranah C2 dan C3 rata-rata orang tua di SMP Sekolah Spring Garden School menyatakan kesulitan membantu anak-anaknya, Berdasarkan masalah tersebut maka tujuan penelitian ini adalah untuk mengetahui seberapa besar peran orang tua terhadap hasil belajar matematika yang belajar secara daring dimasa pandemi COVID-19 di SMP Spring Garden School.

\section{METODE PENELITIAN}

Penelitian ini menggunakan metode kuantitatif dengan teknik survei berupa studi korelasi. Sampel penelitian 72 siswa dari kelas VIIA, VIIB, VIIC, dan VIID semester ganjil tahun pelajaran 2020/2021 di SMP Spring Garden School JABABEKA Cikarang Timur yang diambil secara random. Sampel untuk uji coba instrument 72 siswa juga. Ada dua jenis data yang diambil dalam penelitian ini, yaitu peran orang tua sebagai variabel bebas dan hasil belajar matematika sebagai variabel terikat. Untuk memperoleh data mengenai peran orang tua menggunakan instrumen berupa angket, sedangkan untuk mendapatkan data hasil belajar matematika siswa menggunakan tes berbentuk pilihan ganda, kedua instrumen tersebut sudah valid dan reliabel. Adapun kisi-kisi kedua instrumen tersebut disajikan pada Tabel 1 dan Tabel 2.

Tabel 1. Kisi-kisi Angket Peran Orang Tua

\begin{tabular}{|c|c|c|c|c|}
\hline \multirow{2}{*}{ Variabel } & \multirow{2}{*}{ Indikator } & \multicolumn{2}{|c|}{ Butir Pernyataan } & \multirow{2}{*}{$\begin{array}{l}\text { Jumlah } \\
\text { item }\end{array}$} \\
\hline & & Positif & Negatif & \\
\hline \multirow{4}{*}{$\begin{array}{c}\text { Peran } \\
\text { Orang } \\
\text { Tua }\end{array}$} & $\begin{array}{l}\text { 1. Membimbing anak dalam } \\
\text { belajar }\end{array}$ & $\begin{array}{l}2,3,5,6,7 \\
9,10\end{array}$ & $1,4,8,11$ & 11 \\
\hline & 2. Mengawasi proses belajar & $12,16,17$ & 13,14 & 8 \\
\hline & 3. Memotivasi anak belajar & $20,22,24$ & 21,23 & 7 \\
\hline & $\begin{array}{l}\text { 4. Memenuhi kebutuhan } \\
\text { belajar anak }\end{array}$ & 27,31 & $28,29,30$ & 5 \\
\hline
\end{tabular}

Hasil uji instrument angket diperoleh 31 pernyataan yang valid dan reliabel. 
Tabel 2. Kisi-kisi Instrumen Tes Hasil Belajar Matematika

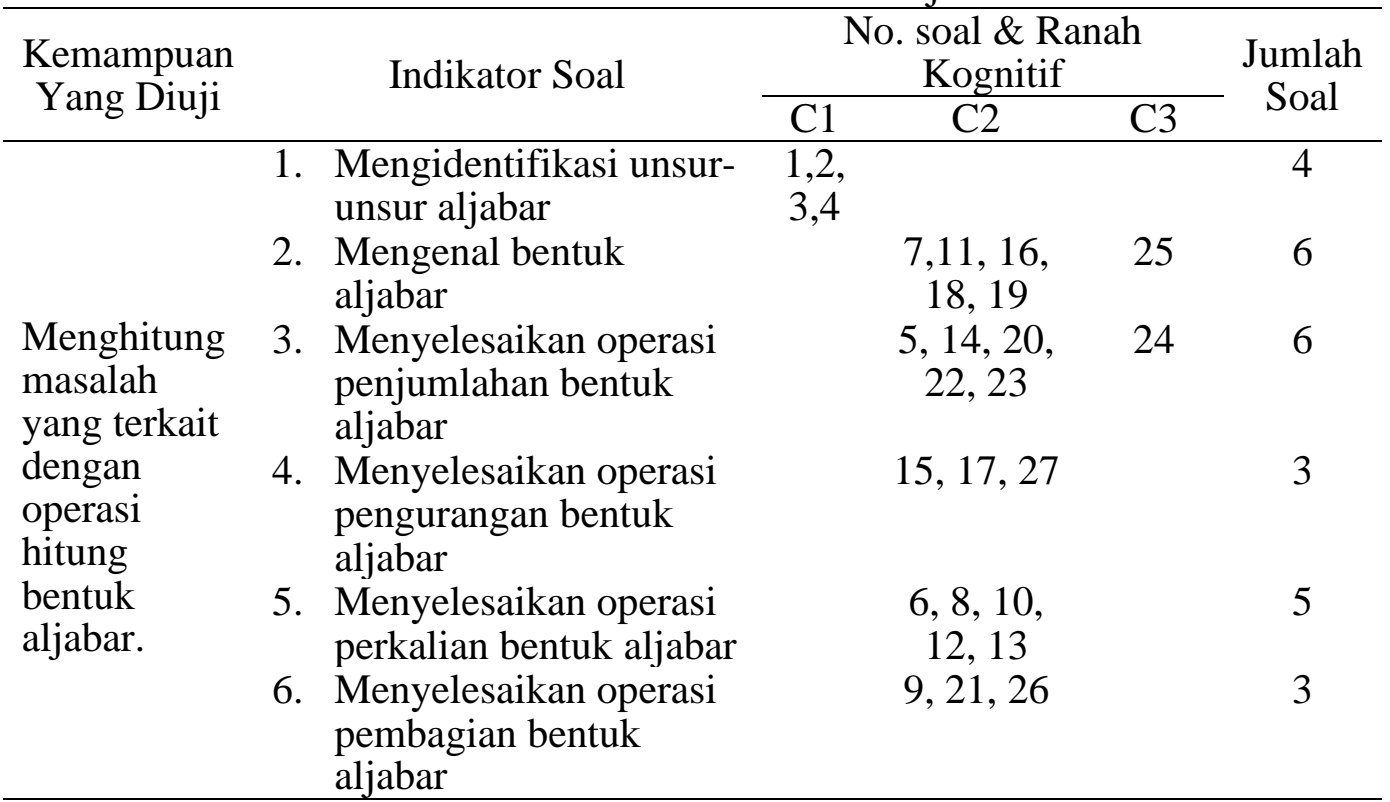

Sedangkan instrumen tes untuk mengukur hasil belajar matematika diperoleh 27 soal yang valid dan reliable. Teknik analisa data diawali dengan uji prasyarat menggunakan uji liliefors (uji normalitas). Setelah memenuhi syarat maka dilakukan uji hipotesis menggunakan uji korelasi product moment dan uji regeresi linier serta dikuatkan dengan uji signifikansi. Uji koefisien determinasi dihitung untuk mengetahui berapa persen kontribusi peran orang tua terhadap hasil belajar matematika.

\section{HASIL DAN PEMBAHASAN}

Hasil penelitian yang diperoleh pada penelitian ini dipaparkan berdasarkan variabel yang diteliti.

\section{Peran Orang Tua}

Data skor variabel peran orang tua, diperoleh skor minimal sebesar 63 dan skor maksimal sebesar 115. Skor rata-rata sebesar 91,61, median sebesar 93,50, modus sebesar 97,00, varians sebesar 157,40 dan simpangan baku sebesar 12,55. Berikut adalah data variabel $\mathrm{X}$ disajikan dalam Tabel 3.

Tabel 3. Data Peran Orang Tua

\begin{tabular}{cccc}
\hline Interval Kelas & Frekuensi & Batas Nyata & Nilai Tengah \\
\hline $63-70$ & 6 & $62,5-70,5$ & 66,5 \\
$71-78$ & 6 & $70,5-78,5$ & 74.5 \\
$79-86$ & 10 & $78,5-86,5$ & 82.5 \\
$87-94$ & 16 & $86,5-94,5$ & 90.5 \\
$95-102$ & 21 & $94,5-102,5$ & 98,5 \\
$103-110$ & 10 & $102,5-110,5$ & 106,5 \\
$111-118$ & 3 & $110,5-118,5$ & 114,5 \\
\hline
\end{tabular}


Agar data terlihat berdistribusi normal digambarkan dengan grafik histogram dan polygon frekuensi dan disajikan pada Gambar 1.

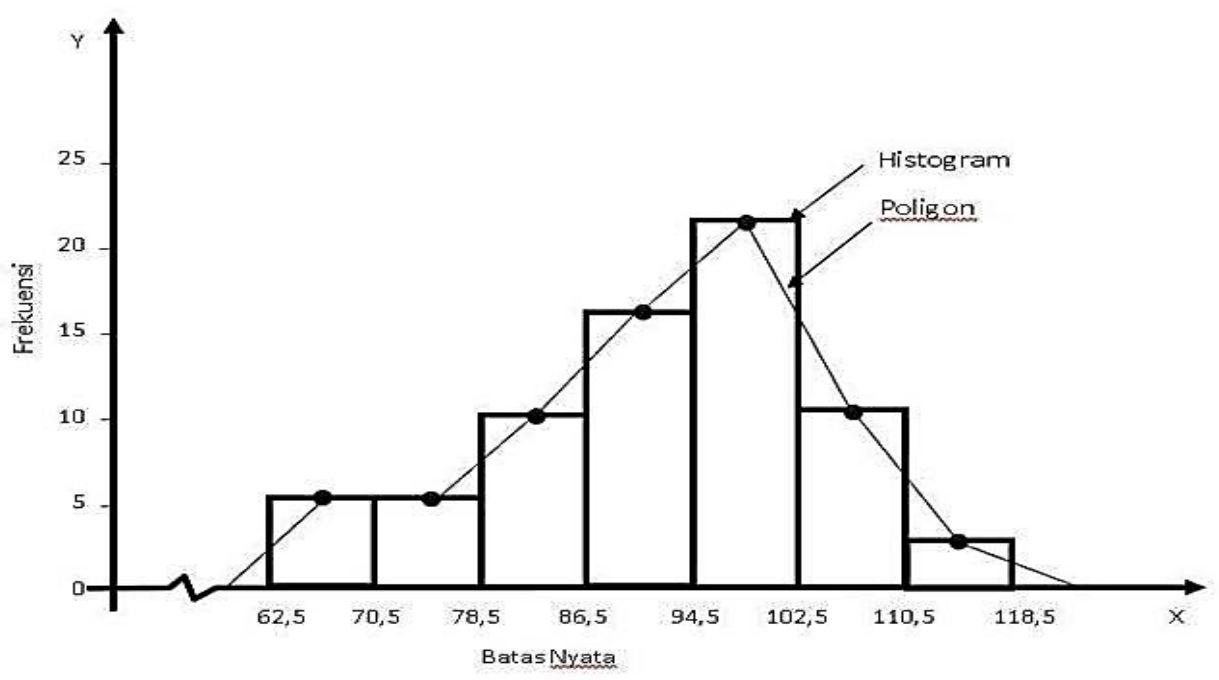

Gambar 1. Histogram dan Poligon Frekuensi

Data Peran Orang Tua

Mengamati Gambar 1, menunjukan data mendekati berdistribusi normal dan condong kearah negatif (kecondongan/skewness negative). Skewness yang bernilai negatif menunjukkan bahwa sebagian besar skor berada di sisi kanan kurva, dan menunjukan skor perhatian orang tua dari jawaban angket siswa lebih banyak yang memperoleh skor tinggi.

\section{Hasil Belajar Matematika}

Data hasil belajar matematika diperoleh skor minimal 7, dan skor maksimal 26. Skor rata-rata sebesar 17,33, median sebesar 17,85, modus sebesar 19,40, varians sebesar 27,27, dan simpangan baku sebesar 5,22. Lebih lengkapnya disajikan pada Tabel 4.

Tabel 4. Data Hasil Belajar Matematika

\begin{tabular}{cccc}
\hline Interval Kelas & Frekuensi & Batas Nyata & Nilai Tengah \\
\hline $7-9$ & 7 & $6,5-9,5$ & 8 \\
$10-12$ & 8 & $9,5-12,5$ & 11 \\
$13-15$ & 10 & $12,5-15,5$ & 14 \\
$16-18$ & 14 & $15,5-18,5$ & 17 \\
$19-21$ & 17 & $18,5-21,5$ & 20 \\
$22-24$ & 10 & $21,5-24,5$ & 23 \\
$25-27$ & 6 & $24,5-27,5$ & 26 \\
\hline
\end{tabular}

Agar lebih jelas data berdistribusi normal disajikan pada Gambar 2. Deskripsi Gambar 2 menunjukan data mendekati berdistribusi normal dan condong kearah negatif (kecondongan/skewness negative) juga. Skewness yang bernilai negatif menunjukkan bahwa sebagian besar nilai siswa berada di sisi kanan kurva, dan menunjukan hasil belajar matematika siswa dari jawaban tes lebih banyak yang memperoleh nilai tinggi. 


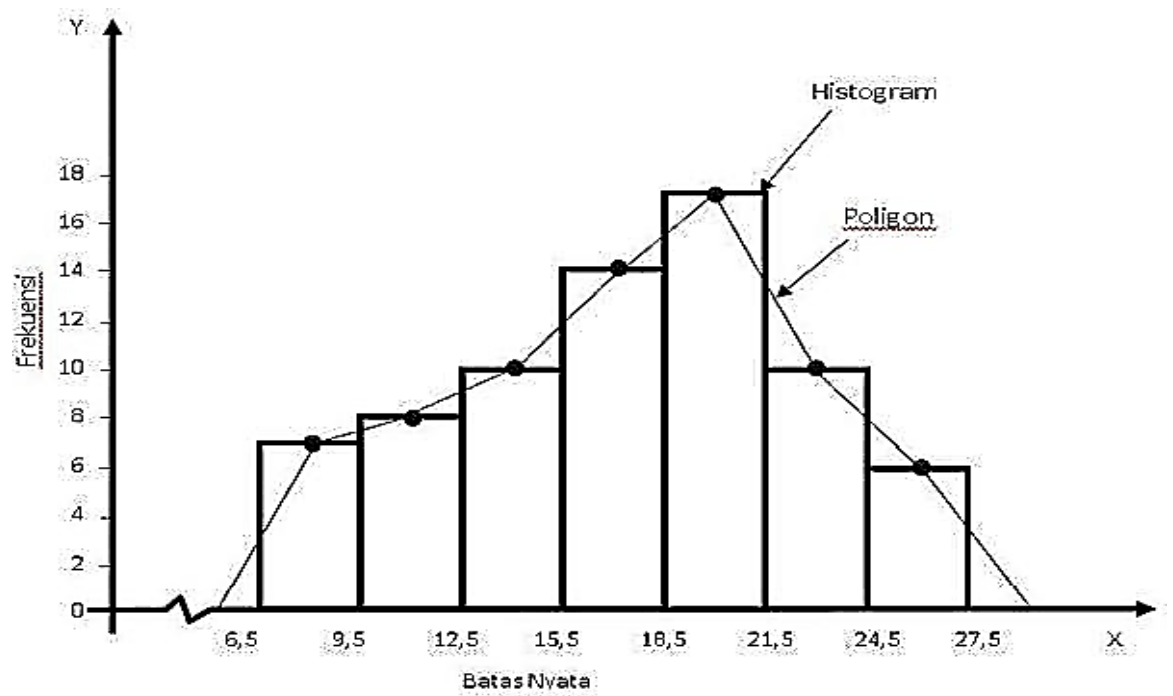

Gambar 2. Histogram dan Poligon Frekuensi

Data Hasil Belajar Matematika

\section{Pengujian Prasyarat Analisis Data}

Hasil perhitungan uji normalitas data peran orang tua pada taraf signifikasi 0,05 diperoleh $L_{\text {hitung }}<L_{\text {tabel }}$ yaitu $0,088<0,104$ sehingga data tersebut berdistribusi normal. Sedangkan uji normalitas pada data hasil belajar matematika diperoleh $L_{\text {hitung }}<L_{\text {tabel }}$ yaitu $0,098<0,1040$ sehingga data tersebut juga berdistribusi normal.

Uji linieritas dihitung untuk mengetahui apakah peran orang tua memiliki hubungan yang linier dengan hasil belajar matematika siswa. Dari perhitungan uji linieritas dengan regresi linier sederhana, diperoleh harga konstanta $(a)$ sebesar 11,19 dan koefisien (b) sebesar 0,31 sehingga persamaan regresinya $\hat{Y}=-$ $11,19+0,31 X$. Apabila digambarkan grafik linieritas seperti pada Gambar 3.

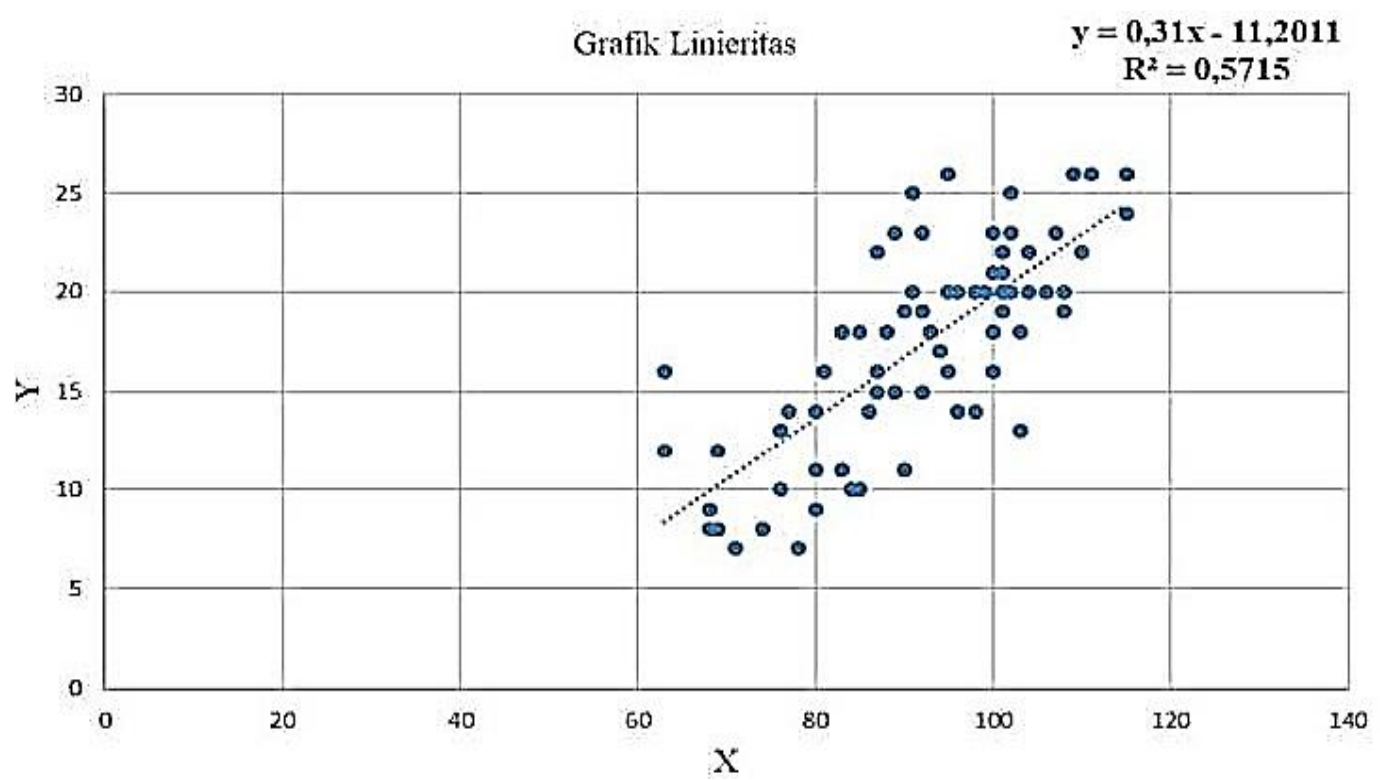

Gambar 3. Grafik sebaran Data Penelitian

Sebaran data hasil penelitian berada disekitar persamaan garis regresi $(\hat{Y})$. Hal ini menginformasikan bahwa data linear kearah posisitf pada taraf signifikan 5\%, 
artinya semakin tinggi peran orang tua maka semakin tinggi hasil belajar matematika siswa.

Selanjutnya dilakukan perhitungan uji regresi dan diperoleh harga $F_{\text {hitung }}=1,075$. Jika dikonsultasikan dengan $F_{\text {tabel }}$ pada taraf singnifikan 0,05 dan $d k=70$ diperoleh $F_{\text {tabel }}=3,98$, ini berarti harga $F_{\text {hitung }}<F_{\text {tabel }}$, dengan demikian $F$ regresi positif signifikan. Rekap perhitungan uji linieritas disajikan pada Tabel 5.

Tabel 5. Analisis Variansi Keberartian Regresi

\begin{tabular}{llcccc}
\hline Sumber Varians & $d k$ & $J K$ & $R J K$ & $F_{\text {hitung }}$ & $F_{\text {tabel }}$ \\
\hline Total & 72 & 233359 & - & & \\
Regresi $(a)$ & 1 & 21459,0139 & 21459,0139 & & \\
Regresi $(b / a)$ & 1 & 1088,23361 & 1088,23361 & 1,075 & 3,98 \\
Residu & 70 & 811,7525 & 11,596 & & \\
Tuna Cocok & 36 & 432,09 & 12,0025 & & \\
Kesalahan (error) & 34 & 379,67 & 11,167 & & \\
\hline
\end{tabular}

Data pada Tabel 5 menunjukan adanya hubungan yang linier kearah positif antara variable peran orang tua terhadap hasil belajar matematika. Hal ini berarti semakin besar peran orang tua maka semakin tinggi pula hasil belajar matematika yang diperoleh siswa. Antara persamaan regresi dan perhitungan uji F menunjukan kedua variable memiliki hubungan linear.

\section{Uji Hipotesis}

Hasil perhitungan statistik variabel peran orang tua dan hasil belajar matematika, disubstitusikan pada rumus Korelasi product-moment dari Pearson $\left(r_{x y}\right)$, diperoleh nilai $r_{\text {hitung }}$ atau $r_{x y}=0,756$. Kontribusi variable $\mathrm{X}$ terhadap $\mathrm{Y}$ dilihat dari besarnya angka koefisien deteriminasi $=r^{2} \times 100 \%$ atau sebesar $57,15 \%$. Berdasarkan uji-t korelasi maka diperoleh hasil $t_{\text {hitung }}>t_{\text {tabel }}$ dengan $d b=70$. Hasil uji korelasi dan uji-t menunjukan adanya hubungan yang berarti, bahwa ada korelasi atau hubungan positif yang signifikan antara peran orang tua dengan hasil belajar matematika. Kontribusi pengaruh peran orang tua dengan hasil belajar matematika sebesar $57,15 \%$.

\section{Pembahasan Hasil Penelitian}

Berdasarkan hasil penelitian yang diperoleh menunjukan bahwa penelitian berhasil membuktikan terdapat hubungan positif yang signifikan antara Peran Orang Tua dengan Hasil Belajar Matematika siswa kelas VII SMP Spring Garden School. Dengan demikian dapat diinterpretasikan bahwa semakin tinggi skor Peran Orang Tua akan diikuti dengan tingginya skor Hasil Belajar Matematika. Hal ini mempunyai makna bahwa makin tinggi Peran Orang Tua akan mempengaruhi tingginya skor hasil belajar matematika siswa. Temuan hasil penelitian ini sejalan dengan hasil penelitian sebelumnya, diantaranya:

1. Hasil penelitian Kurniati dkk., (2020), membuktikan bahwa peran orang tua sebagai pembimbing, pendidik, penjaga, pengembang dan pengawas pada anak di masa pandemi COVID-19 sangat dibutuhkan. Pendampingan orang tua baik dalam belajar maupun menghadapi masa-masa pandemi yang menakutkan dan membosankan, mengurangi rasa takut dan rasa jenuh anak berada di rumah. 
2. Hasil penelitian Ningsih dkk. (2016), membuktikan bahwa terdapat pengaruh positif yang signifikan perhatian orang tua dan kemandirian siswa dalam belajar terhadap prestasi belajar matematika.

3. Yulianingsih dkk. (2020), hasil penelitiannya membuktikan bahwa keterlibatan orang tua dalam pendampingan anak usia PAUD di Cerme Gresik selama belajar dari rumah (BDR) menunjukkan hasil yang sangat baik. Pendampingan dilakukan dengan cara membantu anak mengerjakan tugas sekolah. Orang tua berfungsi sebagai tempat belajar anak, memberikan penjelasan ulang mengenai materi yang dipelajari, memberikan respon yang baik terhadap pembelajaran di sekolah.

4. Fitroturrohmah dkk. (2019), hasil penelitiannya membuktikan bahwa terdapat hubungan yang positif dan signifikan antara peran orang tua dengan prestasi belajar siswa disalah satu SDN di kota Jepara. Besarnya perhatian orang tua terhadap proses belajar anak-anaknya di rumah maupun di sekolah meningkatkan prestasi mereka di sekolah.

Informasi hasil penelitian sebelumnya terlihat jelas ada perbedaan dengan hasil penelitian ini. Diantaranya pada jenjang sampel yang diteliti, pada materi pembelajaran, dan pada variable terikatnya. Untuk penelitian Kurniati dkk. (2020) beserta Yulianingsih dkk. (2020), peran orang tua dibutuhkan untuk anak Usia Dini sedangkan penelitian Ningsih dkk. (2016), perhatian orang tua untuk meningkatkan prestasi belajar matematika siswa SMP, penelitian Fitroturrohmah dkk. (2019), peran orang tua dibutuhkan untuk prestasi siswa-siswa jenjang SD. Dan sampai hasil penelitian ini dipublikasikan, belum ditemukan hasil penelitian yang menyatakan tidak ada hubungan antara peran orang tua terhadap hasil belajar anaknya.

\section{KESIMPULAN}

Penelitian korelasional ini bertujuan untuk memperoleh informasi tentang seberapa besar hubungan peran orang tua dengan hasil belajar matematika siswa SMP kelas VII. Berdasarkan hasil uji statistik yang dilakukan, diperoleh informasi data yang diteliti berdistribusi normal, dan ada hubungan positif yang signifikan antara peran orang tua dengan hasil belajar matematika pada materi aljabar di kelas VII SMP Spring Garden School. Kontribusi pengaruh peran orang tua terhadap hasil belajar matematika sebesar $57,15 \%$. Hubungan bersifat searah, ini berarti, gerak variabel bebas akan diikuti variabel terikat ke arah positif. Jika skor peran orang tua tinggi maka nilai hasil belajar matematika akan tinggi. Begitu pula sebaliknya jika skor peran orang tua rendah maka nilai hasil belajar matematika rendah.

\section{REFERENSI}

Amelia, D., Susanto, S., \& Fatahillah, A. (2016). Analisis Hasil Belajar Matematika Siswa Pada Pokok Bahasan Himpunan Berdasarkan Ranah Kognitif Taksonomi Bloom Kelas VII-A di SMPN 14 Jember. Jurnal Edukasi, 2(1), 1-4. https://doi.org/10.19184/jukasi.v2i1.3402

Anisah, A. S. (2017). Pola asuh orang tua dan implikasinya terhadap pembentukan karakter anak. Jurnal Pendidikan UNIGA, 5(1), 70-84. http://dx.doi.org/10.52434/jp.v5i1.43 
Fitroturrohmah, M., Purwadi, P., \& Azizah, M. (2019). Hubungan Peran Orang Tua Dengan Prestasi Belajar Siswa Kelas Tinggi SDN Kedung 01 Jepara. JANACITTA, 2(2). 26-30. http://dx.doi.org/10.35473/jnctt.v2i2.258

Indrawati, D., Malik, H. A., \& Mansoer, Z. (2020, November). Pengaruh Kelekatan Anak Pada Ibu terhadap Keterampilan Sosial. In Prosiding Seminar Nasional Pendidikan STKIP Kusuma Negara II (pp. 55-59).

Juliya, M., \& Herlambang, Y. T. (2021). Analisis problematika pembelajaran daring dan pengaruhnya terhadap motivasi belajar siswa. Genta Mulia: Jurnal Ilmiah Pendidikan, 12(1). 281-294.

Kurniati, E., Alfaeni, D. K. N., \& Andriani, F. (2020). Analisis Peran Orang Tua dalam Mendampingi Anak di Masa Pandemi COVID-19. Jurnal Obsesi: Jurnal Pendidikan Anak Usia Dini, 5(1), 241-256. http://dx.doi.org/10.31004/obsesi.v5i1.541

Lilawati, A. (2020). Peran orang tua dalam mendukung kegiatan pembelajaran di rumah pada masa pandemi. Jurnal Obsesi: Jurnal Pendidikan Anak Usia Dini, 5(1), 549-558. https://doi.org/10.31004/obsesi.v5i1.630

Martsiswati, E., \& Suryono, Y. (2014). Peran orang tua dan pendidik dalam menerapkan perilaku disiplin terhadap anak usia dini. JPPM (Jurnal Pendidikan dan Pemberdayaan Masyarakat), 1(2), 187-198. https://doi.org/10.21831/jppm.v1i2.2688

Ningsih, R., \& Nurrahmah, A. (2016). Pengaruh kemandirian belajar dan perhatian orang tua terhadap prestasi belajar matematika. Formatif: Jurnal Ilmiah Pendidikan MIPA, 6(1). 73-84. http://dx.doi.org/10.30998/formatif.v6i1.754

Novrinda, N., Kurniah, N., \& Yulidesni, Y. (2017). Peran Orangtua Dalam Pendidikan Anak Usia Dini Ditinjau Dari Latar Belakang Pendidikan. Jurnal Ilmiah Potensia, 2(1), 39-46.

Sudjana, Nana (2009). Penilaian Hasil Proses Belajar Mengajar. Sinar Baru Algesindo.

Suprijono, Agus (2009). Cooperative Learning. Teori \& Aplikasi Paikem. Pustaka Belajar.

Syahrina, A. (2021). Peran Orang Tua Dalam Mendampingi Anak Belajar Daring Pada Masa Pandemi COVID-19 Di MI. Hj Kamisih Kelurahan Duri Timur Kecamatan Mandau Kabupaten Bengkalis (Doctoral dissertation, repository Universitas Islam Negeri Sultan Syarif Kasim (Riau).

Wulandari, W., Zikra, Z., \& Yusri, Y. (2017). Peran orang tua dalam disiplin belajar siswa. JPGI (Jurnal Penelitian Guru Indonesia), 2(1), 24-31. https://doi.org/10.29210/02216jpgi0005

Yoga, D. S., Suarmini, N. W., \& Prabowo, S. (2015). Peran keluarga sangat penting dalam pendidikan mental, karakter anak serta budi pekerti anak. Jurnal Sosial Humaniora (JSH), 8(1), 46-54. http://dx.doi.org/10.12962/j24433527.v8i1.1241

Yulianingsih, W., Suhanadji, S., Nugroho, R., \& Mustakim, M. (2020). Keterlibatan Orangtua dalam Pendampingan Belajar Anak selama Masa Pandemi COVID-19. Jurnal Obsesi: Jurnal Pendidikan Anak Usia Dini, 5(2), 1138-1150. https://doi.org/10.31004/obsesi.v5i2.740 